\title{
Legal nature of the agreement on the use of security measures in relation to criminal proceeding participants
}

\author{
Natalia Vladimirovna Grigoryeva ${ }^{1^{*}}$, Natalia Viktorovna Ugolnikova $^{2}$, Viktor Anatolievich \\ Samoroka ${ }^{2}$, and Olga Evgenievna Zhamkova ${ }^{2}$ \\ ${ }^{1}$ Financial University under the Government of the Russian Federation, Department of International \\ and Public Law, Moscow, Russia \\ ${ }^{2}$ Moscow University of the Ministry of Internal affairs of Russia named after V.Ya. Kikot, \\ Department of Criminal Procedure, Moscow, Russia
}

\begin{abstract}
The relevance of the study is due to the presence of a set of theoretical and practical issues and gaps in the legal regulation of the agreement concluded with the protected person on the conditions of security measures, mutual obligations, and responsibility of the parties. In this regard, based on an independent scientific study, the article attempts to substantiate the legal nature of the specified agreement as a special legal institute based not only on the rules of criminal procedure but also on civil law, since civil law determines the general provisions of agreements. In implementing the provisions of the institute of state protection of criminal proceeding participants, the leading research method is justified as increasing the effectiveness of legal norms on security measures through modeling the most optimal algorithm of the agreement with the person subject to state protection. Based on the results of the data obtained, the analysis of factors positively and negatively affecting the procedure of making decisions on security measures and the conclusion of the agreement was also carried out. The article focuses on the practical orientation of the results, which provide methodological and applied assistance to employees of state protection bodies in criminal cases. As a result of the study, the authors justify the need to develop a standard form of the agreement; the form, structure, and content of the agreement are proposed; the possibility of improving the legal framework through the development and adoption of a particular regulatory legal act of an open nature regulating the order of the agreement in the system of internal affairs bodies is determined. The research will provide academic, organizational, and legal assistance to state defense departments and investigators, inquirers, prosecutors, teachers, students, and anyone interested in ensuring security in criminal proceedings. Keywords: right and freedom protection guarantees, state protection, security, protected person, standard form agreement
\end{abstract}

* Corresponding author: navlagri@mail.ru 


\section{Introduction}

The relevance of the study is due to several points. First, state protection of participants in a trial is an integral part of the guarantees of human and civil rights and freedoms. Conflicts of norms in this institution are a threat to the violation of fundamental constitutional rights. Second, the interest in organizational and legal issues is confirmed by the annual growth in the number of protected persons. In recent years, on average, security measures are applied to 4 thousand people annually. At the moment, according to data for the six months of 2020 , the security of more than 2,000 protected people has been ensured, in respect of which 5,500 security measures have been applied.

The issues of ensuring security in criminal proceedings are given much attention in legal science and law enforcement practice in Russia and foreign countries [1, 2]. Studies of doctors of law $[3,4]$ made a significant contribution to the consideration of specific issues of the state witness protection program.

It is proved that today security measures are an effective system of legal grounds used to prevent and block various threats (property, physical nature) by specially authorized bodies and officials [5].

The authors of the article set out to explain the grounds, conditions, and procedure for applying security measures to determine the legal nature of the agreement concluded with the protected person. This goal allows solving the problem associated with improving the efficiency of the state protection bodies by developing scientifically based recommendations on the algorithm of actions of employees of state protection and preliminary investigation bodies when applying security measures.

\section{Methods}

The improvement of security issues in criminal proceedings was noted in a significant number of studies, which served as a methodological basis for solving the tasks of the article [6-8].

It is established that the research is devoted to various aspects of state protection in criminal proceedings: a review of security measures in the system of procedural guarantees for ensuring participants' rights in criminal proceedings [6] and selected witness protection programs [8], separate consideration of the protection of victims and witnesses [7, 9, 10]. The need to increase the types of security measures of a criminal procedural nature [11] and ensure increased security of participants in criminal proceedings [3, 12, 17].

Most of the research carried out is based on the study of theoretical material and issues regulation.

However, today there are many problems both at the time of drawing up and signing the agreement and at the time of its termination due to the cancellation of security measures. The authors identified some of them in the course of interviewing practitioners during classes at the Faculty of Retraining and Advanced Training held at the Moscow State University of the MIA of Russia named after V. Ya. Kikot in the 2019-2020 academic year (on the subject of the study, 30 state defense employees arrived from different regions were interviewed), as well as in the analysis of responses to requests from territorial authorities. In the case of refusal of the protected person from state protection measures, the authorities that decided to apply them refuse to decide on their cancellation on far-fetched grounds and sometimes do not respond at all to the petitions submitted. For example, specialized units of the state protection of MIA of Russia in 2017-2020, 19 petitions were sent to the Republic of Bashkortostan's investigative bodies and courts for the cancellation of security measures due to violation of the agreement terms. According to the results of the considered petitions, four petitions were granted for the entire period. The authors believe that there is no unified 
approach to determining the legal status of a request to cancel security measures since state protection bodies are not recognized as participants in criminal proceedings.

This article is a modern attempt to substantiate the theoretical and methodological foundations for determining the grounds, conditions, and procedure for applying and canceling security measures. The study is based on the analysis of practical materials of state protection units.

In this paper, the "gaps" in the legal regulation of the agreement concluded with the protected person are considered.

\section{Results}

The basis of the legal relationship between the client and the body implementing security measures is an agreement [13]. The question of the legal nature of this agreement, its necessity, the standard form is debatable in law enforcement practice.

It is necessary to start with a general description of the mechanism for concluding an agreement with a person subject to state protection. The algorithm includes the following steps: receiving a message about a security threat, verifying the message and making a decision on state protection, concluding an agreement.

Assessment of the emerging threats when deciding on the appointment and selection of security measures is of particular importance in implementing the first two stages $[14,15]$.

The gaps in the legal regulation cause the formality of checking the threat and, as a result, the unreasonableness of the final decision.

The conclusion of an agreement is the basis for the implementation of legal relations in the context of security measures, so the verification of the procedural form of the agreement is the basis of the legality of law enforcement practice.

\section{Discussion}

The law on the state protection of victims, witnesses, and other participants in criminal proceedings and civil legislation provides for the conclusion of a written agreement that defines the conditions for applying the chosen security measure, the rights and obligations of the body implementing the security measures, and the protected person.

However, neither federal legislation nor departmental regulations offer a standard form of this agreement.

Analyzing the normative acts, it can be concluded that when concluding this Agreement, the general provisions on the agreement contained in Subsection 2 of Section III of the Civil Code of the Russian Federation apply. However, the law on state protection eliminates the possibility of entering into this agreement in verbal form.

In the practical activities of employees of the internal affairs bodies, the form of the agreement is understood as its actual content and structure (or the form of the agreement of an approximate or definite and established form).

The conclusion of this Agreement is mandatory [16]. The legal form of the Agreement is established by Part 4 of Article 14 of Law No. 45-FZ and Part 6 of Article 18 of Law No. $119-\mathrm{FZ}$ and is also determined by the security bodies' regulatory legal acts (bodies implementing security measures). Simultaneously, a number of such bodies (the FSB, the Federal Penitentiary Service, Federal National Guard Troops Service, the Ministry of Defense) have issued relevant orders. For example, the order of the FSB of Russia dated June 25, 2018 No. 293 "On approval of the procedure for concluding an agreement with a person subject to state protection, or sending him instructions, compliance with which is necessary to ensure his safety". 
The MIA of Russia has not issued a departmental regulatory legal act of an open nature regulating the procedure for concluding an agreement.

Cases of applying security measures to persons who lead an antisocial, parasitic lifestyle with low social responsibility are common. In some cases, for the investigator, the use of such measures is a way to ensure a person's appearance for the production of investigative actions.

To begin with, it is necessary to decide - is protection a right or a duty? It is logical to assume that the signed consent and agreement by the protected person is purely voluntary.

Although the general provisions of the agreement are applied at the conclusion of this agreement, the practice does not provide for the procedure for its termination, and these items are not prescribed in the agreement itself.

After analyzing the consequences of agreement obligations between the parties, it becomes evident that in practice, regardless of the efforts and means spent and violations of the terms of the agreement by the protected party, the termination of the agreement by the protected person does not bear the burden of responsibility of the latter, since the subject of the agreement is to ensure the safety of the protected person.

The next group of issues is caused by the lack of precise requirements for the agreement. According to law enforcement officials, it is impossible to consider all the nuances, so it is impossible to prepare a standard agreement. However, it is possible to regulate the essential terms of the agreement.

The practice of drawing up an agreement in a single copy, which after signing is stored in the body that implements security measures, is due to maintaining the secrecy and does not contradict Article 434 of the Civil Code of the Russian Federation. The second party's information to the agreement is provided by the delivery of an extract from the agreement. The practice analysis showed the lack of a uniform understanding of the information required by the second party. In some cases, the statement contains the minimum information (number, date, place of storage); in others - an extract from the agreement containing all the essential terms of the agreement is issued, and in some regions, the protected person is issued a memo on the rules of conduct in the application of security measures.

To prevent violations of the agreement terms, such an extract must contain the rights and obligations of the protected person, liability, and other essential terms of the agreement. However, this moment causes disputes among law enforcement officials due to the need to preserve security activities' secrecy.

Measures of civil liability of the parties for violations of the terms of the agreement, the grounds and procedure for termination of its validity should be included as additional terms of the agreement. It is appropriate to reflect in the "Term of the agreement" section the provision that the obligations of the parties cease together with the cancellation of security measures.

The practice analysis of applying the agreement on state protection revealed several issues, including issues related to the grounds for termination of its validity, which is also of interest but is subject to research in other works.

\section{Conclusion}

In connection with the above, the authors believe that the general requirements for the form, structure, and content of the agreement should be fixed in departmental regulations, including those of an open nature. All the nuances that are not subject to disclosure and relate to restricted access information can be reflected in the appendix. Such information is stored separately.

The person of the agreement, being one of the parties, must understand the essence of this activity and study the procedure from publicly available sources. 
The presence of many legal gaps leads to an undue expansion of the discretionary powers of the law enforcement officer.

To solve this problem, it is necessary to fill in the normative regulation: special departmental instructions, amendments, and additions to the criminal procedure legislation, as well as through explanations of the Plenum of the Supreme Court of the Russian Federation.

\section{References}

1. S.A. Zuev, Criminal Law, 6, 84-86 (2007)

2. F. Enikö, Revue internationale de droit pénal ,77(1/2), 313-322 (2006). https://doi.org/10.3917/ridp.771.0313

3. A. Epihin, A. Mishin, Kazan University Law Review, 1, 29-46 (2018). https://doi.org/10.30729/2541-8823-2018-3-1-29-46

4. L.V. Brusnitsyn, Obespechenie bezopasnosti lits, sodeistvuiushchikh ugolovnomu pravosudiiu: mirovoi opyt i razvitie rossiiskogo zakonodatelstva (protsessualnoe issledovanie) [Security of persons assisting in criminal justice: world experience and development of Russian legislation (procedural study)] (Yurlitinform, Moscow, 2010)

5. D.S. Sokolov, Nekotorye voprosy gosudarstvennoi zashchity uchastnikov ugolovnogo sudoproizvodstva [Some issues of state protection of participants of criminal proceedings], in Teoriia i praktika rassledovaniia prestuplenii. Materialy VIII Mezhdunarodnoi nauchno-prakticheskoi konferentsii [Theory and practice of crime investigation. Materials of the Eighth International Scientific-Practical Conference], 302-306 (Krasnodar University of the Ministry of Internal Affairs of Russia, Krasnodar, 2020)

6. D. Bazarova, Int. J. Psychosoc. Rehabilitation 24(2), 287-294 (2020). https://doi.org/10.37200/ijpr/v24i2/pr200333

7. S. Bhuckory, Commonwealth Law Bulletin 39(1), 43-48 (2013). https://doi.org/10.1080/03050718.2012.751198

8. Y. Dandurand, K. Farr, A review of selected witness protection programs (Public Safety Canada, Ottawa, 2010)

9. D.T. Dimovski, J.M. Papovic-Miladinovic, Zbornik radova Pravnog fakulteta, Novi Sad 51(1), 137-152 (2017). https://doi.org/10.5937/zrpfns51-14142

10. F.F. Zaripov, Bulletin of Udmurt University. Series Economics and Law, 29(6), 823829 (2019). https://doi.org/10.35634/2412-9593-2019-29-6-823-829

11. A. Dmitrieva, Tomsk State University Journal, 396, 111-115 (2015). https://doi.org/10.17223/15617793/396/20

12. O.V. Ilchenko, A.V. Benko, Comparative-Analytical Law, 5 (2019). https://doi.org/10.32782/2524-0390/2019.5.94

13. K.A. Krasnova, N.V. Ivlieva, Police and Investigative Activity, 2, $72-86$ (2015). https://doi.org/10.7256/2409-7810.2015.2.15457

14. T.B. Ramazanov, R.O. Radzhabov, Law Herald of Dagestan State University, 29(1), 128-132 (2019). https://doi.org/10.21779/2224-0241-2019-29-1-128-132

15. T.B. Ramazanov, R.O. Radzhabov, Law Herald of Dagestan State University, 30(2), 146-150 (2019). https://doi.org/10.21779/2224-0241-2019-30-2-146-150

16. V.A. Panteleev, Protsessualnyi poriadok deistvii organov i dolzhnostnykh lits, obespechivaiushchikh bezopasnost uchastnikov ugolovnogo sudoproizvodstva (na 
primere MVD Rossii) [Procedural order of actions of bodies and officials providing safety of participants of criminal legal proceedings (on the example of the MIA of Russia)], in Pravo: istoriia, teoriia, praktika: materialy IV mezhdunarodnoi nauchnoi konferentsii (g. Sankt-Peterburg, iiul 2016 g.) [Law: history, theory, practice: proceedings of the Fourth International Scientific Conference (St. Petersburg, July 2016)], 94-96 (Svoe izdatelstvo, Saint Petersburg, 2016)

17. D.S. Lanshakov, Bulletin of Udmurt University. Series Economics and Law, 30(1), 99104 (2020). https://doi.org/10.35634/2412-9593-2020-30-1-99-104 